\title{
Ethnobotanical Survey of Medicinal Plants Used in Curing Some Diseases in Infants in Abeokuta South Local Government Area of Ogun State, Nigeria
}

\author{
L. O. Shosan1, 0. O. Fawibe1, A. A. Ajiboye"2, T. A. Abeegunrin1, D. A. Agboola1* \\ ${ }^{1}$ Department of Biological Sciences, Federal University of Agriculture, Abeokuta, Nigeria \\ ${ }^{2}$ Department of Plant Science and Biotechnology, Federal University, Oye-Ekiti, Nigeria \\ Email: ${ }^{*}$ jareagbo@yahoo.com
}

Received 12 August 2014; revised 16 September 2014; accepted 19 October 2014

Copyright (C) 2014 by authors and Scientific Research Publishing Inc.

This work is licensed under the Creative Commons Attribution International License (CC BY). http://creativecommons.org/licenses/by/4.0/

(c) (i) Open Access

\section{Abstract}

An ethnobotanical survey of medicinal plants used in curing some diseases in infants in Abeokuta South Local Government Area of Ogun State, Nigeria was carried out between February and June, 2012. Ethnobotanical data were collected by oral interview with the aid of a semi-structured questionnaire administered to fifty (50) respondents made up of traditional medical practitioners (TMPs), herbalists and herb sellers. From the survey, a total of 63 plant species belonging to 33 families were found to be useful in the treatment of cold, malaria, fontanel, diarrhoea, typhoid, chicken pox, measles and small pox. Recipes used in the treatment of these ailments were documented. Herbal remedies were either prepared from dry or freshly collected plants while the traditional solvents of choice includes water, pure honey, lime and aqueous extracts from fermented maize. The methods of preparation were decoction and infusion while method of administration ranges from 1 drop to 1 teaspoonful daily. Survey revealed that leaves form the major part of plant for herbal preparations. Residents in the study area find the traditional medicine cheaper as compared to orthodox medicines. It is therefore implicated that efforts should be made on how to improve on documentation, conservation and standardization of the medicinal plants in Nigeria. Also, attention of the scientists and health officials should be drawn to the importance and various uses of the medicinal plants and they should intensify on the research to reveal other concealed values.

\section{Keywords}

Ethnobotany, Survey, Medicinal Plant, Abeokuta, Nigeria

\footnotetext{
${ }^{*}$ Corresponding author.
} 


\section{Introduction}

The term ethnobotany was first coined by an American botanist John Harshburger, in 1896, in an attempt to study the plants used by the primitive and aboriginal people. Since then, it has been defined as the traditional knowledge of indigenous communities, about surrounding plant diversity and how various people make use of indigenous plants found in their localities. Ethnobotany involves the study of how communities of a particular region make use of indigenous plants in the region for food, clothing and medicine [1].

Plants are significant sources of medicines that are used in the treatment of various categories of human diseases. Historically all medicinal preparations were derived from plants, whether in the simple form of plant parts or in the more complex form of crude extracts, mixtures, etc. Today a substantial number of drugs are developed from plants which are active against number of diseases [2].

The majority of these involve the isolation of the active ingredient (chemical compound) found in a particular medicinal plant and its subsequent modification. In the developed countries $25 \%$ of the medical drugs are based on plants and their derivatives [2] and the use of medicinal plants is well known among the indigenous people in rural areas of many developing countries. Plants, especially the higher ones have been described as the sleeping giants of drug and these medicinal plants have been screened for their chemicals that are potentially potent [3]. Many of the medicinal plants, especially in Nigeria have been documented [4]. The importance of medicinal plants, and the contribution of phytomedicine to the well-being of a significant number of the world's population, has attracted interest from a variety of disciplines [5].

Infancy, a period marked by the most rapid physical growth and development of a person's life. In Nigeria the need to reduce infant and child morbidity and mortality is one of the greatest challenges confronting the Federal government. It has been estimated that the mortality rate of children below five years of age in Nigeria hovers between 97 and 120 per thousand births [6] [7]. The greatest health challenge to the Federal government of Nigeria is to reduce this rate to the barest minimum; but despite the efforts of various successive governments to tackle the problem, the results have been dismally poor. Various researchers who are interested in maternal and child health in Nigeria have identified some key factors that may be adduced to this problem and some of these factors include poverty [8]; ignorance by mothers [9]; and the lack of political will by the Federal government [10]. For these and other similar reasons, morbidity and mortality from childhood diseases continue their debilitating effects on the health of young children. The major causes of poor health and premature death among children in the developing world are not rare or exotic diseases. Millions of children in developing countries die each year from common illnesses such as malaria, measles, convulsion, mumps, mouth ulcer, chicken pox, kwashiorkor, small pox, cholera, pertussis (whooping cough), diarrhea, pneumonia, and especially in sub Saharan Africa-malaria. Newborns die from delivery complications, cold, tetanus and infections. Thus the aim of this study was to document the medicinal plants used for the treatment of some diseases in infants from Nigeria flora.

\section{Materials and Methods}

Ethnobotanical survey was carried out between February 2012 and June 2012 to obtain relevant information about medicinal plants used in the treatment of various diseases in infant in Abeokuta South Local Government Area of Ogun State. Data collected was based on oral interview with the aid of semi-structured questionnaire from respondents. Plants specimens indicated in the recipes were collected, pressed, mounted, identified and authenticated using their local names and standard text [11]. Voucher specimens were deposited at forestry and wildlife herbarium of the Federal University of Agriculture Abeokuta.

\subsection{Study Area}

The survey was carried out in Itoku $\left(7.15662^{\circ} \mathrm{N}, 3.34135^{\circ} \mathrm{E}\right)$, Kuto $\left(7.13943^{\circ} \mathrm{N}, 3.35074^{\circ} \mathrm{E}\right)$, Adatan $\left(7.17070^{\circ} \mathrm{N}\right.$, $\left.3.35960^{\circ} \mathrm{E}\right)$ and Ijaye $\left(7.15221^{\circ} \mathrm{N}, 3.35757^{\circ} \mathrm{E}\right)$ all in Abeokuta South Local Government Area of Ogun State, Nigeria. Abeokuta is located within Latitude $7.1608^{\circ} \mathrm{N}$ and Longitude $3.3483^{\circ} \mathrm{E}$. Abeokuta is surrounded by large mass of rocks and has a population of about six hundred thousand people [12]. The city covers the geopolitical areas of Abeokuta North and Abeokuta South Local Government Areas of Ogun State. The Yorubas are the main ethnics in the area but the original settlers are those of the Egba Yoruba dialect who founded the historic city. The dialectical groups in the area include Egbado, Ijebu, Egba, Remo, Oyo (Owu), Awori, Ikale and Ilaje. The people are known for traditional arts, carving and sculpturing [13]. 


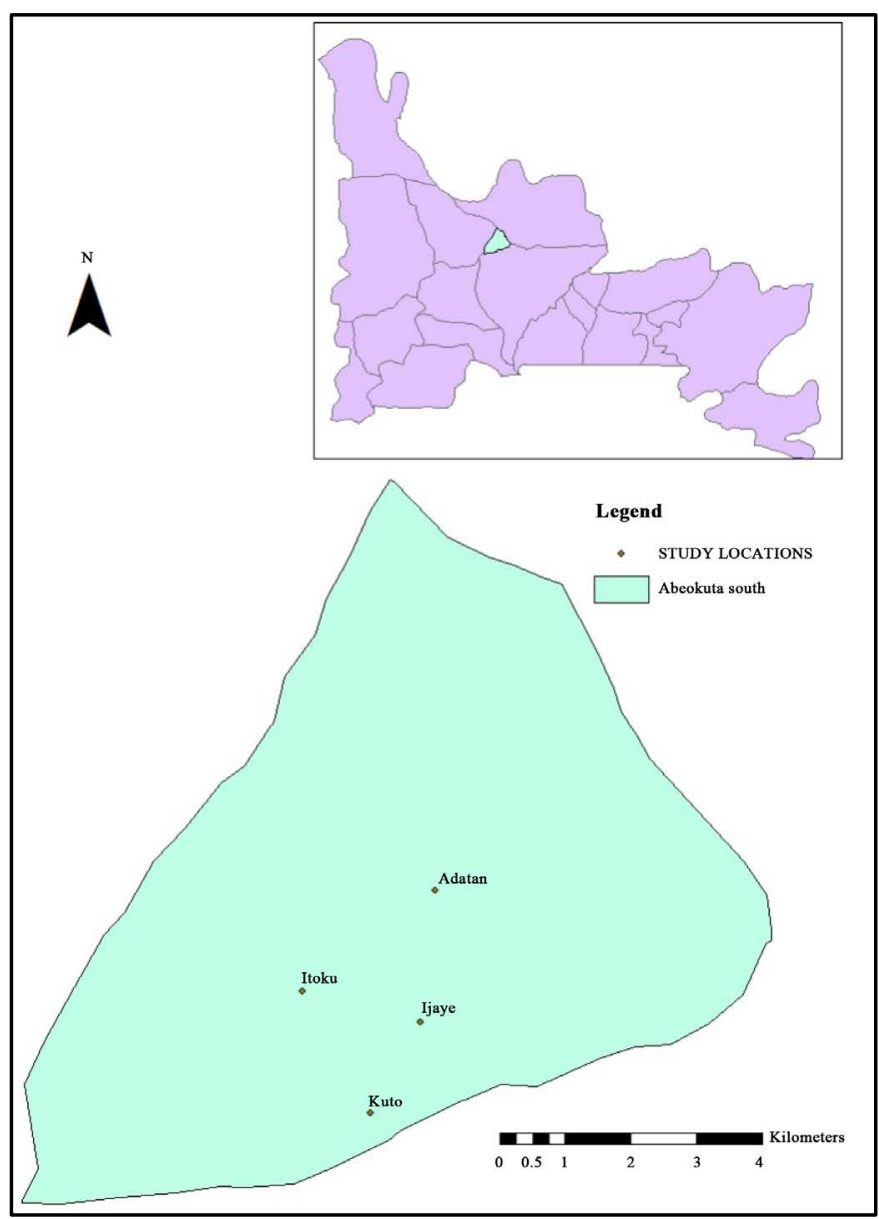

\subsection{Ethical Approval}

The purpose of the study was explained to the respondents (Herb sellers, traditional medical practitioner and herbalist) in the Local Government Area and informed consent was obtained from each of the respondents.

\subsection{Administration of Questionnaire}

Fifty-two (52) people were selected from these four study area. 13 people from each location. Ethnobotanical information on the plants was obtained from 50 respondents out of the total selected. These constituted the Traditional Medicinal Practitioners (TMPs), herb sellers and herbalists. The use of semi-structured questionnaire and oral interview were adopted to obtain relevant ethno medicinal data. The questionnaires were administered to the respondents. The questionnaire was divided into three sections.

Section 1 deals with demographic information such as age, sex, religion, nationality, practice specification, duration of practice and educational background.

Section 2 consist of professional experience on the treatment of diseases and includes question such as type of diseases treated, frequency of treatment, use of herbal therapy alone or otherwise, duration of treatment, accompanied side effects, accompanied verbal instructions, plant part(s) frequently used, availability of plants/plant part(s) and knowledge of treatment.

In Section 3, plants and recipes used in the treatment of common diseases, herbal preparation, arrangement of plant part(s) ingredient, traditional solvent of choice, traditional extraction methods/method of preparation and method of administration were considered.

In terms of educational background, majority of the respondent were not literate. The questionnaire was translated and interpreted to them orally in the local language and responses filled into the questionnaire after each interview. 


\subsection{Data Analysis}

All data were entered and verified using Epi-Info software (version 6.04; Centers for Disease Control Prevention, Atlanta, GA) and analyzed using SPSS version 16.0 for windows (SPSS Inc., Chicago, IL, USA).

\section{Results}

\section{Demography/Personal Information on Respondents}

The survey showed a total of 50 respondents, interviewed through the use of semi-structure questionnaire. The respondents were mainly herb sellers (80\%), Traditional Medical Practitioners (TMPs) (12\%), TMPs/herb sellers (4\%) and herbalists (4\%). The demographic survey of respondents was represented in Table 1.

Table 2 showed the professional experience of respondents. The survey showed that only $2 \%$ of the respondents use other therapies such as incantations to aid treatment of their patients. The survey also showed that (80\%) inherited their knowledge of herbal treatment from their ancestors while $(10 \%)$ got the knowledge from formal training, (8\%) both from formal training and ancestors while (2\%) claimed that their knowledge was from divination. Also (94\%) of the respondents documented no accompanied side effects while (4\%) indicated nausea/vomiting as accompanied side effect.

The entire survey revealed that a total of 63 medicinal plant species from 36 families were used by the various practitioners. Botanical names, local names, common names, family, growth form and plant part used were presented in Table 3. Table 4 showed the species distribution according to their families while Table 5 revealed the percentage of plant growth form and plant part used in the treatment of the common diseases in infants. Table 6 showed the ailments, enumeration of recipes, methods of preparation and mode of administration.

\section{Discussion}

Plants have been a major source of medicine for human kind. The demand for traditional herbs is increasing very rapidly, mainly because of the harmful effects of synthetic chemical drugs. The global clamor for more herbal ingredients creates possibilities for the local cultivation of medicinal and aromatic crops as well as for the regulated and sustainable harvest of wild plants. Such endeavors could help raise rural employment in the developing countries, boost commerce around the world and perhaps contribute to the health of millions [14]. Ni-

Table 1. Demographic structure of the respondents on the knowledge of plants used in the treatment infant diseases.

\begin{tabular}{ccc}
\hline Parameter & Specification & N (\%) \\
\hline Practice specification & Herb sellers & $40(80)$ \\
& Traditional medical practitioners & $2(12)$ \\
& Traditional medical practitioners/Herb sellers & $2(4)$ \\
& Herbalists & $10(20)$ \\
Sex & Male & $40(80)$ \\
& Female & $1(2)$ \\
Age (years) & $1-20$ & $18(36)$ \\
& $21-40$ & $25(50)$ \\
& $40-60$ & $6(12)$ \\
Religion & $>60$ & $12(24)$ \\
& Islam & $10(20)$
\end{tabular}

$\mathrm{N}$ = number of respondents; \% = percentage of respondents. 
Table 2. Professional experience of the respondents on the knowledge of plants used in the treatment infant diseases.

\begin{tabular}{ccc}
\hline Parameters & Specification & N (\%) \\
\hline Frequency of treatment & Regular & $44(88)$ \\
Duration of treatment (Days) & Irregular & $3(12)$ \\
& 1 & $39(5)$ \\
Other treatments apart from herbs & $2-3$ & $4(8)$ \\
& Divination/Oracle/Incantation/Animal part & $1(2)$ \\
Source of knowledge & None & $49(98)$ \\
Availability of plant/plant parts & Parental & $40(80)$ \\
Accompanied side effects & Training & $5(10)$ \\
& Parental/Training & $4(8)$ \\
& Divination & $1(2)$ \\
\hline
\end{tabular}

$\mathrm{N}$ = number of respondents; \% = percentage of respondents.

geria is endowed with an enormous diversity of animals and plants, both domesticated and wild, and an impressive variety of habitats and ecosystems. This heritage sustains the food, medicinal, clothing, shelter, spiritual, recreational, and other needs of her population [15].

Respondents gave local names of plants in recipes used in the treatment of some infant diseases. This was in consonance with Singh (2008) [16] who reported that plants are generally known by their local names in every part of the world. The local names play a vital role in ethnobotanical study of a specific tribe or region. Although local names are not recommended directly for scientific accounts as they lack uniformity and consistency, yet they may certainly be considered as a useful tool for search of new useful plants or new uses of known plants [17]. Local names render a useful service as a means of reference by local people in a particular area.

This work revealed that majority (80\%) of the respondents acquired the source of knowledge from their ancestral via verbal transfer. Ogbole and Ajaiyeoba (2010) [18] had earlier reported that knowledge of the uses of plants, which is sometimes jealously guarded by their owners, is a tradition passed on from one generation to the other by verbal transfer, the changes imposed by modern life on social structures and attitudes now seems to be the cause of the loss or rejection of such indigenous practices.

The study also showed that quite a number of plant parts from the 63 species especially the leaves, roots and stem barks have been found to be efficient in the management of various diseases in infants in the Local Government Area. Information gathered from respondents showed that increasing number of people is turning to herbal remedies for prevention and cure of various diseases. The 63 medicinal plants mentioned were represented by all plants forms. Trees were found to be the most used plants followed by shrubs, herbs, underground stem, grass, climber, creeper and weed.

The various plants parts mentioned include bulb, fruit, leaves, rhizome, root, seed, stem bark and whole plants. It was observed that leaves formed the most frequently used (47.62\%), followed by stem bark (23.81\%), seed (7.93\%), roots (6.34\%), fruits $(4.76 \%)$, bulb, rhizome and whole plants $(3.17 \%$ each). The plant leaves are important ingredient in traditional treatment of various diseases as it features as a component in many herbal prep- 
Table 3. Enumeration of plants used for the treatment of some common diseases in infants by the people of Abeokuta South Local Government Area.

\begin{tabular}{|c|c|c|c|c|c|}
\hline Botanical Name & Local Name & Common Name & Family & Habit & Part(s) Used \\
\hline Mangiferaindica Linn. & Mangoro & Mango & Anarcadaceae & Tree & $\begin{array}{l}\text { Stem bark, } \\
\text { leaves }\end{array}$ \\
\hline Lanneawelnitschii (Hiern) Engl & Orira & Kumbi & Anarcadaceae & Tree & Stem bark \\
\hline Spondiasmombin Linn. & Iyeye & Hog plum & Anarcadaceae & Tree & Stem bark \\
\hline Uvariachamea P. Beauv. & Eruju & Cluster pear & Annonaceae & Tree & Stem bark \\
\hline Xylopiaaethiopia (Dun.) A. Rich. & Eru & Ethiopian pepper & Annonaceae & Tree & Seed \\
\hline Monodoramyristica Dunal & Ariwo & Calabash nutmeg & Annonaceae & Tree & Seed \\
\hline Alstoniaboonei R. Br. & Ahun & Pattern wood & Apocynaceae & Tree & $\begin{array}{l}\text { Stem bark, } \\
\text { leaves }\end{array}$ \\
\hline Rauwolfiavomitoria Afzel. & Asofeyeje & African rauwolfia & Apocynaceae & Shrub & $\begin{array}{l}\text { Stem bark, } \\
\text { leaves }\end{array}$ \\
\hline Calotropisprocera $\mathrm{R} . \mathrm{Br}$ & Bomubomu & Milk weed & Apocynaceae & Shrub & Leaves \\
\hline Picralimanitida Stapf Th. \& H. Dur. & Abere & Picralima & Apocynaceae & Tree & Seed \\
\hline Aristolochiaringens Vahl. & Akogun & Dutchman's pipe & Aristolochiaceae & Climber & Root \\
\hline $\begin{array}{l}\text { Chromolaenaodorata (L.) King \& } \\
\text { H. E. Robins. }\end{array}$ & Akintolataku & Siam weed & Asteraceae & Shrub & Leaves \\
\hline Agerantumconizoides Linn. & Imi-esu & Goat weed & Asteraceae & Herb & Leaves \\
\hline Vernoniaamygdalina Delile & Ewuro & Bitter leaf & Asteraceae & Shrub & Leaves \\
\hline Kigeliaafricana (Lam.) Benth. & Pandoro & Sausage tree & Bignoniaceae & Tree & Leaves \\
\hline Carica papaya Linn. & Ibepe & Pawpaw & Caricacea & Tree & Fruit, leaves \\
\hline $\begin{array}{l}\text { Hippocrateaindica (Hutch. \& M. B. } \\
\text { Moss) }\end{array}$ & Ponjuowiwi & Bitter sweet & Celestraceae & Shrub & $\begin{array}{l}\text { Root and } \\
\text { leaves }\end{array}$ \\
\hline $\begin{array}{l}\text { Terminaliaavicennioides Guill. \& } \\
\text { Perr. }\end{array}$ & Idin & Baushe & Combretaceae & Tree & Leaves \\
\hline Guierasenegalensis J. F. Gmel. & Saabara & Moshi medicine & Combretaceae & Shrub & Leaves \\
\hline Mormodicacharantia Descourt. & Ejinrin-wewe & Bitter gourd & Cucurbitaceae & Creeper & Leaves \\
\hline $\begin{array}{l}\text { Lagenariabreviflorus (Benth.) } \\
\text { Roberty }\end{array}$ & Itagiri & Pseudoclocynth & Cucurbitaceae & Creeper & Fruit \\
\hline $\begin{array}{l}\text { Kyllinganemoralis Dandy ex Hutch. } \\
\text { \& Dalziel }\end{array}$ & Keregun & White water sedge & Cyperaceae & Weed & Seed \\
\hline $\begin{array}{l}\text { Acalyphawilkesiana (Muell. Arg.) } \\
\text { Fosberg. }\end{array}$ & Jinwini & Copper leaf & Euphorbiaceae & Shrub & Leaves \\
\hline Manihotesculentum Crantz. & Paki & Cassava & Euphorbiaceae & Shrub & Leaves \\
\hline Caesalpiniabonduc (L.) Roxb & Ayo & Gray nicker & Fabaceae & Shrub & Leaves \\
\hline Cassia fistula Linn. & Aidan-toro & Golden shower & Fabaceae & Tree & Leaves \\
\hline $\begin{array}{l}\text { Daniellaoliveri (Rolfe) Hutch. \& } \\
\text { Dalz. }\end{array}$ & Uya/Iya & Copaibalsam & Fabaceae & Tree & $\begin{array}{l}\text { Stem bark, } \\
\text { Leaves }\end{array}$ \\
\hline $\begin{array}{l}\text { Prosopisafricana (Guill. \& Perr.) } \\
\text { Taub. }\end{array}$ & Ayan & African prosopis & Fabaceae & Tree & Leaves \\
\hline Baphianitida Lodd. & Irosun & Camwood & Fabaceae & Tree & Leaves \\
\hline $\begin{array}{l}\text { Pilostigmareticulatum (DC.) } \\
\text { Hochst. }\end{array}$ & Abafe & Pilostigma & Fabaceae & Tree & Stem bark \\
\hline Cajanuscajan (L.) Millsp. & Otili & Pigeon pea & Fabaceae & Shrub & Leaves \\
\hline $\begin{array}{l}\text { Harunganamadagascariasis Lam. } \\
\text { ex Poiret }\end{array}$ & Asunje & Dragon blood tree & Hyperiaceae & Tree & Stem bark \\
\hline Ocimumgratissimum Linn. & Efinrin & Scent leaf & Lamiaceae & Shrub & Leaves \\
\hline
\end{tabular}




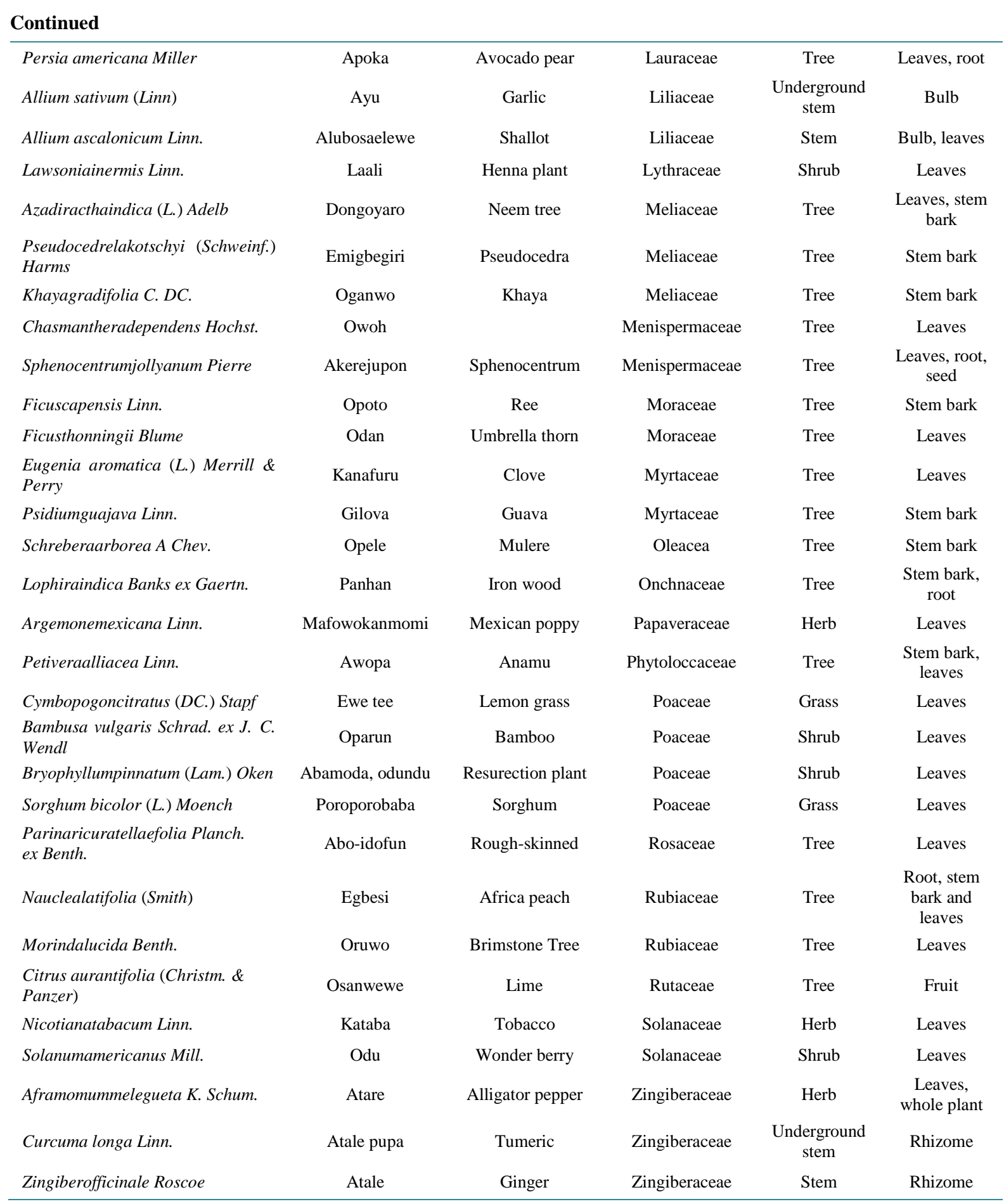

arations. This finding concurred with other studies such as [19].

However, most informants opined that there is no side effect in taking herbal recipes.

Some of the plants revealed in the survey have been cited in the ethnobotanical survey of some African countries, for example in the treatment of measles, jaundice, polimylitis, yellow fever, chicken pox [19], anti malaria [20]. The prominent plant species are Cajanuscajan, Allium sativum, Carica papaya, Momordicacharantia, Garcina kola, Vernonia amygdalina and Aframomum melegueta.

One of the recipes is prepared from a single plant source (Parinari curatellaefolia) while some others are in 
Table 4. Species distribution according to families of plants used for the treatment of some common diseases in infants.

\begin{tabular}{|c|c|}
\hline Family & Number of species \\
\hline Anarcadaceae & 3 \\
\hline Annonaceae & 3 \\
\hline Apocynaceae & 4 \\
\hline Aristolochiaceae & 1 \\
\hline Asteraceae & 3 \\
\hline Bignoniaceae & 1 \\
\hline Caricaceae & 1 \\
\hline Celestraceae & 1 \\
\hline Combretaceae & 2 \\
\hline Crassulaceae & 1 \\
\hline Cucurbitaceae & 2 \\
\hline Cyperaceae & 1 \\
\hline Euphorbiaceae & 2 \\
\hline Fabaceae & 7 \\
\hline Hyperiaceae & 1 \\
\hline Lamiaceaea & 1 \\
\hline Lauraceae & 1 \\
\hline Liliaceae & 2 \\
\hline Lythraceae & 1 \\
\hline Meliaceae & 3 \\
\hline Menispermaceae & 2 \\
\hline Moraceae & 2 \\
\hline Myrtaceae & 2 \\
\hline Oleacea & 1 \\
\hline Onchnaceae & 1 \\
\hline Papaveraceae & 1 \\
\hline Phytoloccaceae & 1 \\
\hline Poaceae & 3 \\
\hline Rosaceae & 1 \\
\hline Rubiaceae & 2 \\
\hline Rutaceae & 1 \\
\hline Solanaceae & 2 \\
\hline Zingiberaceae & 3 \\
\hline
\end{tabular}

Table 5. Percentage of plant growth form and plant part used in the treatment of some common diseases in infants by people of Abeokuta South Local Government.

\begin{tabular}{cccc}
\hline Plant growth form & N (\%) & Plant part & N (\%) \\
\hline Climber & $2(3)$ & Bulb & $2(3)$ \\
Creeper & $1(2)$ & Fruit & $3(5)$ \\
Grass & $2(3)$ & Leaves & $30(48)$ \\
Herb & $5(8)$ & Rhizome & $2(3)$ \\
Shrub & $12(19)$ & Root & $4(6)$ \\
Tree & $36(57)$ & Seed & $5(8)$ \\
Underground stem & $4(6)$ & Stem bark & $15(24)$ \\
Weed & $1(2)$ & Whole plant & $2(3)$ \\
\hline
\end{tabular}

$\mathrm{N}$ = number of plant growth form or plant part; \% = percentage of plant growth form or plant part. 
Table 6. Enumeration of recipes, method of preparation, mode of administration used in the treatment of some infant diseases among the residents of Abeokuta South Local Government.

\begin{tabular}{|c|c|c|c|c|}
\hline Disease & Recipe & $\begin{array}{l}\text { Traditional } \\
\text { Solvent of Choice }\end{array}$ & $\begin{array}{l}\text { Method of } \\
\text { Preparation }\end{array}$ & Mode of Administration \\
\hline \multirow[t]{2}{*}{ Common Cold } & Citrus aurantifolia & Pure honey & Juice & Give little quantity to baby \\
\hline & Allium sativum & Water & Decoction & $\begin{array}{l}\text { Put it on the baby's nose, chest } \\
\text { and back }\end{array}$ \\
\hline \multirow[t]{2}{*}{ Fever } & $\begin{array}{l}\text { Allium sativum, } \\
\text { Cympobogoncitrates }\end{array}$ & Water & Decoction & Give little quantity to baby \\
\hline & $\begin{array}{l}\text { Nauclealatifolia, } \\
\text { Hippocrateaindica, } \\
\text { Petiveraalliacea, Mangiferaindica, } \\
\text { Aframomummeleguata, } \\
\text { Cympobogoncitrates }\end{array}$ & Water & Decoction & Give little quantity to baby \\
\hline \multirow[t]{2}{*}{ Diarrhoea } & $\begin{array}{l}\text { Terminaliaavicennioides, } \\
\text { Lawsoniainermis }\end{array}$ & Water & Infusion & Give little quantity to baby \\
\hline & $\begin{array}{l}\text { Chromolaenaodorata, } \\
\text { Ocimumgratissimum, } \\
\text { Prosopisafricana }\end{array}$ & Water & Decoction & Give little quantity to baby \\
\hline \multirow[t]{6}{*}{ Skin Rashes } & Azadiracthaindica & Water & Decoction & Use for baby bath \\
\hline & Azadiracthaindica & Palm oil & Grinding & Apply paste externally \\
\hline & Acalyphawilkesiana & Water & Decoction & $\begin{array}{l}\text { Use for baby bath every } \\
\text { morning }\end{array}$ \\
\hline & Agerantumconizoides & Water & Decoction & $\begin{array}{l}\text { Use for baby bath every } \\
\text { morning }\end{array}$ \\
\hline & $\begin{array}{l}\text { Daniellaoliveri, Nauclealatifolia, } \\
\text { Pseudocedrelakotschyi, } \\
\text { Terminaliaavicennioides, }\end{array}$ & Water & Decoction & Use for baby bath \\
\hline & $\begin{array}{l}\text { Ficuscapensis, Mangiferaindica, } \\
\text { Uvariachamea, } \\
\text { Pilostigmareticulatum, } \\
\text { Xylopiaaethiopica }\end{array}$ & Water & Decoction & Use for baby bath \\
\hline Measles & $\begin{array}{l}\text { Cajanuscajan, Baphianitida, } \\
\text { Caesalpiniabonduc, } \\
\text { Vernoniaamygdalina, } \\
\text { Bambusa vulgaris, } \\
\text { Bryophyllumpinnatum, } \\
\text { Lagenariabreviflorus, } \\
\text { Argemonemexicana, } \\
\text { Manihotesculentum }\end{array}$ & Water/Black soap & $\begin{array}{l}\text { Decoction/ } \\
\text { Ginding }\end{array}$ & $\begin{array}{l}\text { Boil all the recipes except } \\
\text { Manihotesculentum. Give little } \\
\text { quantity to baby and mix grinded } \\
\text { Manihotesculentum with black } \\
\text { soap to bath the baby every } \\
\text { morning }\end{array}$ \\
\hline \multirow[t]{2}{*}{ Typhoid } & $\begin{array}{l}\text { Lophiraindica, Mangiferaindica, } \\
\text { Khayagradifolia, Sorghum bicolor }\end{array}$ & Water & Decoction & $\begin{array}{l}\text { Give baby little quantity to } \\
\text { drink and use the remaining to } \\
\text { bath the baby }\end{array}$ \\
\hline & $\begin{array}{l}\text { Hippocrateaindica, } \\
\text { Chasmantheradependes, } \\
\text { Nauclealatifolia, } \\
\text { Petiveraalliacea, Cassia fistula, } \\
\text { Alstoniaboonei, Curcuma longa, } \\
\text { Lagenariabreviflorus, } \\
\text { Mangiferaindica, } \\
\text { Sphenocentrumjollyanum }\end{array}$ & Water & Decoction & Give little quantity to baby \\
\hline Funtanelle & $\begin{array}{l}\text { Persia americana, } \\
\text { Guierasenegalensis, Bambusa } \\
\text { vulgaris, Lanneawelnitschii, } \\
\text { Schreberaarborea }\end{array}$ & Water & Decoction & Give little quantity to baby \\
\hline Abdominal Cramp & $\begin{array}{l}\text { Allium ascalonicum, Allium } \\
\text { sativum, } \\
\text { Kyllinganemoralis, } \\
\text { Xylopiaaethiopica }\end{array}$ & Paste & Grinding & $\begin{array}{l}\text { Paste is applied externally to the } \\
\text { abdominal cord. }\end{array}$ \\
\hline
\end{tabular}




\section{Continued}

\begin{tabular}{|c|c|c|c|c|}
\hline & $\begin{array}{l}\text { Rauwolfiavomitoria, } \\
\text { Aristolochiaringens, } \\
\text { Allium ascalonicum, Eugenia } \\
\text { aromatica, } \\
\text { Sphenocentrumjollyanum, } \\
\text { Picralimanitida, } \\
\text { Monodoramyristica, Morindalucida }\end{array}$ & Water & Infusion & Give little quantity to baby \\
\hline \multirow[t]{2}{*}{ Jaundice } & $\begin{array}{l}\text { Lawsoniainermis, } \\
\text { Solanumamericanus, } \\
\text { Harunganamadagascariasis }\end{array}$ & Water & Decoction & Give little quantity to baby \\
\hline & $\begin{array}{l}\text { Vernoniaamygdalina, } \\
\text { Zingiberofficinale, Psidiumguajava, } \\
\text { Mangiferaindica, } \\
\text { Azadiracthaindica, Alstoniaboonei, } \\
\text { Calotropisprocera, } \\
\text { Rauwolfiavomitoria, } \\
\text { Khayagradifolia, Spondiasmombim, } \\
\text { Ficusthonningii, } \\
\text { Ocimumgratissimum }\end{array}$ & Water & Decoction & Give little quantity to baby \\
\hline Poliomylitis & $\begin{array}{l}\text { Kigeliaafricana, } \\
\text { Aframomummeleguata, } \\
\text { Nicotianatobaccum }\end{array}$ & & Strong heating & $\begin{array}{l}\text { Ashes from burnt leaves are } \\
\text { used to rub the affected parts }\end{array}$ \\
\hline Cough & Parinaricuratellaefolia & Water & Infusion & Give little quantity to baby \\
\hline
\end{tabular}

combinations with other common plants. Method of preparation varies decoctions and infusions are the most frequently used methods.

Some of the challenges encountered in the course of this survey include: respondents not willing to give relevant information due to fear of losing their major source of their income, some demanded money prior to interview as they claimed to have "intellectual properties" stocked with knowledge of medicinal plants, while some castigated government for neglecting them and sending researchers to come and exploit their ethnomedicinal knowledge. Also, some herbalists/TMPs preferred sharing the knowledge on a television programme rather than disseminating ethnomedicinal information to researchers. This they claimed will also help to advertise their names and services.

\section{Conclusion}

The survey has added more to the existing discoveries of the relevance of plants and its usefulness in the treatment of some infant diseases among the residents of Abeokuta South Local Government. The therapeutic claimed recipes incorporated in the study need to be evaluated through phytochemical, pharmacological investigation to discover their active compounds.

\section{References}

[1] Aiyeloja, A.A. and Bello, O.A. (2006) Educational Research and Review, 16-22. www.academicjournal.org/ERR

[2] Principe, P. (2005) Monetising the Pharmacological Benefits of Plants. US Environmental Protection Agency, Washington DC, 1991.

[3] Fahnsworth, N.R. (1988) Screening Plants for New Medicines. In: Wilson, E.O., Ed., Biodiversity, National Academic Press, Washington DC, 83-97.

[4] Gill, L.S. (1992) Ethnomedicinal Uses of Plants in Nigeria. UNIBEN Press, Benin City, 275.

[5] Biapa, P.N., Agbor, G.A., Oben, J.E. and Ngogang, J.Y. (2007) Phytochemical Studies and Antioxidant Properties of Four Medicinal Plants Used in Cameroon. Afr. J. Trad. CAM, 4, 495-500.

[6] UNICEF (2001) The State of the World Children.

[7] World Health Organisation (2005) Estimates of the Causes of Death in Children. The Lancet, 365, 1147-1152. http://dx.doi.org/10.1016/S0140-6736(05)71877-8

[8] Owumi, B.E. and Ezeogu, A. (2003) Poverty and HIV/AIDS Patient Management in Swaziland: A Case Study of Known HIV/AIDS Patients. In: Munyae, M. and Pempelani, M., Eds., Debt Relief Initiatives and Poverty Alleviation. 
Lessons from Africa, African Century Publications, South Africa, 189-196.

[9] Bradley, A.K. and Giles, H.M. (1984) Malunfashi Endemic Diseases Research Project, 21 Pointers to Causes of Death in the Malunfashi Area, Northern Nigeria. Annals of Tropical Medical Parasitology, 78, 265-271.

[10] Iyun, B.F. and Oke, E.A. (2000) Ecological and Cultural Barriers to Treatment of Childhood Diarrhea in Riverine Areas of Ondo State, Nigeria. Social Science \& Medicine, 50, 953-964. http://dx.doi.org/10.1016/S0277-9536(99)00347-0

[11] Gbile, Z.O. (2002) Vernacular Names of Nigeria Plants (Yoruba). Forestry Research Institute of Nigeria (FRIN), Ibadan, 124.

[12] GeoNames Geographical Database (2012) Population of Abeokuta, Nigeria. http://population.mongabay.com/population/nigeria/2352947/abeokuta

[13] Idu, M., Erhabor, J.O. and Efijuemue, H.M. (2010) Documentation on Medicinal Plants Sold in Markets in Abeokuta, Nigeria. Tropical Journal of Pharmaceutical Research, 9, 110-118. http://dx.doi.org/10.4314/tjpr.v9i2.53696

[14] Anita, M. (2004) Medicinal and Aromatic Plants: Monitoring the Effectiveness of Biological Conservation. http://www.confound.org/global/global.html

[15] Odugbemi, A. and Akinsulire, O. (2006) Medicinal Plants by Species Names. University of Lagos Press, Lagos, 95156.

[16] Singh, H. (2008) Importance of Local Names of Some Useful Plants in Ethnobotanical Study. Indian Journal of Traditional Knowledge, 7, 365-370.

[17] Erinoso, S.M. and Aworinde, D.O. (2012) Ethnobotanical Survey of Some Medicinal Plants Used in Traditional Health Care in Abeokuta Areas of Ogun State, Nigeria. African Journal of Pharmacy and Pharmacology, 6, 1352-1362. http://dx.doi.org/10.5897/AJPP12.127

[18] Ogbole, O.O. and Ajaiyeoba, E.O. (2010) Traditional Management of Tuberculosis in Ogun State of Nigeria: The Practice and Ethnobotanical Survey. African Journal of Traditional, Complementary and Alternative Medicines, 7, 79-84. http://dx.doi.org/10.4314/ajtcam.v7i1.57270

[19] Oladunmoye, M.K. and Kehinde, F.Y. (2011) Ethnobotanical Survey of Medicinal Plants Used in Treating Viral Infections among Yoruba Tribe of South Western Nigeria. African Journal of Microbiology Research, 5, 2991-3004.

[20] Clarkson, C., Maharaj, V.J., Crouch, N.R., Grace, O.M., Pillay, P. and Matsabisa, M.G. (2004) In Vitro Antiplasmodial Activity of Medicinal Plants Native to or Naturalised in South Africa. Journal of Ethnopharmacology, 92, 177-191. http://dx.doi.org/10.1016/j.jep.2004.02.011 
Scientific Research Publishing (SCIRP) is one of the largest Open Access journal publishers. It is currently publishing more than 200 open access, online, peer-reviewed journals covering a wide range of academic disciplines. SCIRP serves the worldwide academic communities and contributes to the progress and application of science with its publication.

Other selected journals from SCIRP are listed as below. Submit your manuscript to us via either submit@scirp.org or Online Submission Portal.
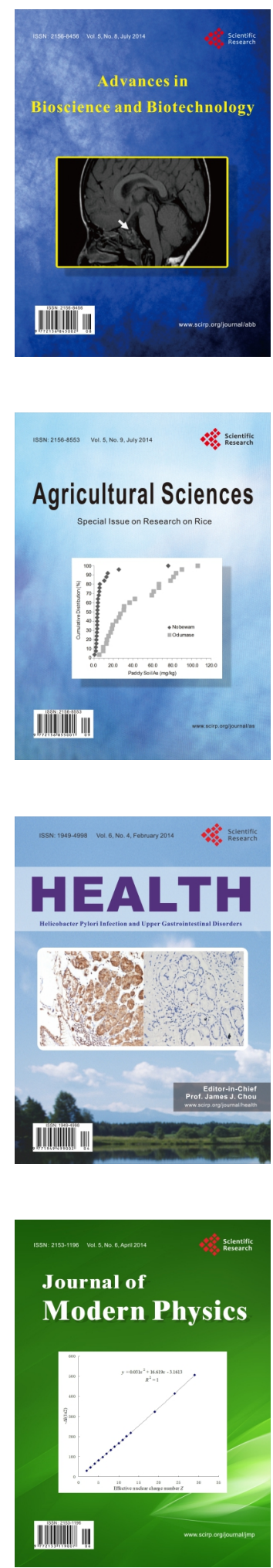
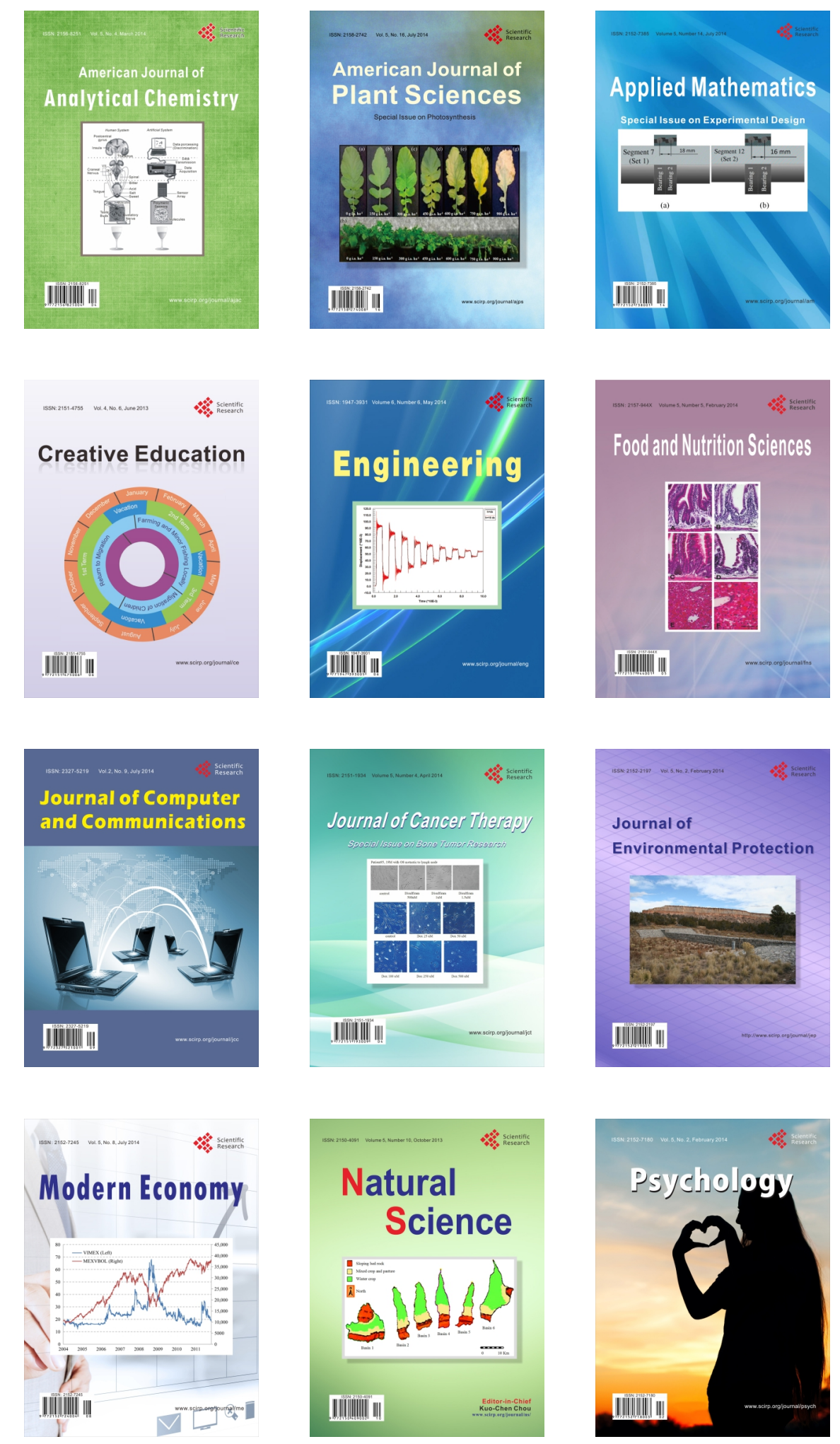